\title{
The Entanglement of Zimbabwe in the US-China Geoeconomic Frictions: Defining Winners and Losers
}

\author{
Gorden Moyo${ }^{1}$, Mbongeni Nhliziyo² ${ }^{2}$ Rodrick Fayayo ${ }^{3}$ \\ ${ }^{1}$ Faculty of Social Sciences and Humanities, Lupane State University, Lupane, Zimbabwe \\ ${ }^{2}$ Development Studies Department, Lupane State University, Lupane, Zimbabwe \\ ${ }^{3}$ Department of Political Science, University of the Western Cape, Bellville, South Africa \\ Email: gordenmoyo@gmail.com
}

How to cite this paper: Moyo, G., Nhliziyo, M., \& Fayayo, R. (2020). The Entanglement of Zimbabwe in the US-China Geoeconomic Frictions: Defining Winners and Losers. $i B u-$ siness, 12, 81-102.

https://doi.org/10.4236/ib.2020.123006

Received: July 9, 2020

Accepted: August 31, 2020

Published: September 2, 2020

Copyright (c) 2020 by author(s) and Scientific Research Publishing Inc. This work is licensed under the Creative Commons Attribution International License (CC BY 4.0).

http://creativecommons.org/licenses/by/4.0/ (c) (i) Open Access

\begin{abstract}
This article discusses the undercurrents of US-China geoeconomic competition in Zimbabwe. It argues that while the rivalry between the United States and China has been visible at global level as demonstrated by the high profile tariff wars, South China Sea squabbles, and more recently, for the handling of the origins of the coronavirus aka Covid-19 pandemic, the US-China geoeconomic frictions have largely been of low intensity but high impact on Zimbabwe. The episodes of turfing between Beijing and Washington in that country are traceable to the 2000s when the United States and the other Western countries imposed targeted measures and sanctions on Harare following disagreements on land reform, human rights, rule of law, and electoral malpractices. The imposition of restrictive measures on Zimbabwe was accompanied by the withdrawal of the Euro-American investments, trade, finance, and development aid. In response, the Zimbabwe government invited China to invest in the lucrative sectors of the economy. This signalled the birth of the US-China geoeconomic competition in Zimbabwe. Since then, Beijing has consolidated its geostrategic interests in the country while the United States and the other Western countries have largely remained on the economic sidelines for the past two decades in Zimbabwe. This article therefore sets out to surface the US-China geopolitical and geoeconomic undercurrents thereby identifying the winners and losers as well as opportunities for the ailing economy of Zimbabwe.
\end{abstract}

\section{Keywords}

China, Geoeconomics, Sanctions, U.S, Zimbabwe 


\section{Introduction}

It is almost trite to say that the United States and China are currently involved in a combination of geopolitical and geoeconomic competition reminiscent of the Cold War era. In recent years, the two global powers have been clashing over a wide array of issues including those of currency manipulation, unfair trade, intellectual property theft, cyber espionage, and more recently about the origins of the coronavirus aka Covid-19 pandemic. While the frictions between these two superpowers have been highly visible at global level as demonstrated by their high profile tariff wars, South China Sea squabbles, and about the Covid-19 pandemic blame game, it will be argued that in Zimbabwe, the contestations have been largely indirect and relatively of low profile. And yet, the impact has been deep and painful to the ordinary Zimbabweans.

To be clear, the contours of the low level geoeconomic tensions between Washington and Beijing in Zimbabwe are traceable to the end tail of the 1990s and early 2000s when the relations between Harare and the Euro-American powers together with their juridical economic institutions, in particular, the International Monetary Fund (IMF) and the World Bank became tenuous. The tumultuous relationship was occasioned by a melange of factors including the accusations of human rights abuse, rule of law, electoral malfeasance, and corruption, among others, in Zimbabwe. On the other hand, as the third Newtonian's law of motion would say, "for every action there is an equal and opposite reaction", the then President of Zimbabwe Robert Mugabe equally blamed the Euro-American powers, in particular the British for reneging on its Lancaster House promise for financing the land reform programme in the country. He also accused the Western countries for racism, neo-colonialism, and for harbouring regime change agendas against his government (Ndimande \& Moyo, 2018).

These accusations and counter-accusations culminated in the imposition of sanctions and targeted measures by the United States and the other Western powers on Zimbabwe. Consequently, the Euro-American investors, lenders, creditors, and donors left the country in droves following the rupture between Harare and the Western metropoles. In particular, some Anglo-American multinational corporations followed their governments' cues and disinvested from Zimbabwe. In response, the then Mugabe regime courted and revived its wartime friendship with Beijing. Fortuitously for Mugabe, this period coincided with Beijing's "Going Global Policy" where China was expanding its geopolitical and geoeconomic footprint to the African continent and to the rest of the world in search of markets, raw materials, energy security, political influence, and global leadership (Nantulya, 2019; Barton, 2018).

Not surprisingly, China seized the opportunity and stepped-up its investment as over 4000 white commercial farmers and scores of Western multinational corporations disinvested from Zimbabwe. Moreover, Harare welcomed the Chinese and offered them contracts in the lucrative sectors of the economy including mining, agriculture, construction, infrastructure, and telecommunications 
among others. Today, China has huge claims in the diamond, platinum, coal, and chrome subsectors in Zimbabwe effectively replacing the Euro-American companies, investors, and creditors in those sectors.

Apparently, following, the ousting of Robert Mugabe by the military in November 2017, his predecessor, Emmerson Mnangagwa has continued on the grammar of the Sino-Zimbabwe relations at the same time pursuing a re-engagement strategy with the Euro-American countries (Moyo, 2019; Ndimande \& Moyo, 2018). Thus, since his inauguration in 2017 Mnangagwa has been inviting the Euro-American countries, investors, creditors, lenders, and donors back to Zimbabwe assuring them that his government is "open for business" and that it is "a Second Republic" that represents a break from the Mugabe era. However, there has been very little uptick in takers of this call. Perhaps one of the reasons is that there is very little left in Zimbabwe in terms of key investment opportunities after Harare has mortgaged most of the country's key national resources to the Chinese investors, Chinese state-owned enterprises, and Chinese entrepreneurs (Moyo, 2019). Against this backdrop, this article sets out to surface the US-China geoeconomic undercurrents thereby defining the winners and losers in Zimbabwe's troubled economy.

The article is based on the data obtained from key informant interviews with three senior management members of the Reserve Bank of Zimbabwe (RBZ); two principal directors from the Ministry of Finance and Economic Development; a retired employee of the World Bank Office in Zimbabwe; two Western diplomats currently accredited to Zimbabwe, three Chinese businessmen, three members of civil society organisations that are working on public finance management and debt issues; three captains of industry that represent some business associations; three Members of Parliament (two opposition and one ruling party); a Deputy Minister of the Republic of Zimbabwe; and three members of the press (one independent and two state media). To respect the anonymity of these individuals the interviews were off record. The study also benefited from documentary evidence and online sources.

The rest of the article is structured as follows: section 2 provides the global geopolitical context; section 3 examines the duo of geoeconomics and geopolitics in Africa; section 4 locates the entanglement of Zimbabwe in the midst of the US-China geoeconomic competition; section 5 defines the winners and losers in the US-China competition in Zimbabwe; Sections 6 and 7 gestures into the future and concludes the discussion respectively.

\section{Geoeconomics: Conceptual and Contextual Issues}

There is no better perch from which to analyse the current global rivalries than the discursive context of geoeconomics. This term was minted by a mercurial American strategist Edward Luttwak in 1990 who used it to describe the post-Cold War era. Luttwak noted that "the methods of commerce are displacing military methods-with disposable capital in lieu of firepower, civilian inno- 
vation in lieu of military-technical advancement, and market penetration in lieu of garrisons and bases. State ... will not disappear but reorient themselves toward 'geoeconomics' ... the best term I can think of to describe the admixture of the logic of conflict with the methods of commerce" (Luttwak, 1990: p. 9).

Developing on Luttwak's ideas, the Pacific Tech (2018) defined geoeconomics as referring to economic instruments such as investments, foreign aid, currency, sanctions, and trade as well as cyber and digital policies that are deployed by powerful countries in pursuit of their geopolitical objectives. These economic instruments are generally deployed by the economically powerful to promote and defend their national interests and to produce beneficial geopolitical results. In particular, powerful countries such as the United States and more recently China have been asserting their geoeconomic and geopolitical interests in the major regions of the world including Southeast Asia, Middle-East, Latin America, Eurasia, and Africa.

Until recently the United States has been occupying the geostrategic spaces in all these regions as a sole geopolitical superpower. In concert with its Atlantic allies such as the UK, the EU, and Japan, the United States deployed its huge economic, political, and military resources to police the world as well as inculcate the Washington Consensus including the neoliberal principles of de-regulation, de-controlling, de-statisation, de-subsidisation, and downsizing among others, across the globe.

However, in recent times, the world is witnessing the phenomenon of the shifting geographies of power and economy from the global North to the global South. The global system is transitioning from the unipolar moment of the United States to the emerging multipolar world order (Moyo, 2019). This thesis contends that the transAtlantic trilateral core of the United States and its partners, Japan, the EU, and the UK no longer enjoy the virtual monopoly over global economic power and has ceased to dominate the global public goods such as international trade, development aid, investment, climate change, and conflict resolution among others. Instead, a coterie of re-emerging middle powers such as Brazil, India, Indonesia, Korea, Mexico, Russia, Saudi Arabia, and Turkey led by China are steadily increasing their global clout and influence thereby rearranging the global matrices of power and economy.

Viewed from this perspective, the United States no longer has the overarching global authority to dictate its values and impose its will on Beijing and the other emerging middle powers from the South. This is because Beijing has developed its own economic, political, military, and diplomatic resources to advance its own national and global ambitions as well as counter the United States wherever there is a clash of interests (Moyo, 2019). Consequently, the two superpowers are now involved in a cut-throat geoeconomic and geopolitical competition which has global repercussions and Zimbabwe is entangled in this global friction as will be explained anon.

Apparently, the Trump-administration which was elected to office on an "America First" policy has been turbo-charging the global geoeconomic and 
geopolitical tensions. To be clear, since the emergence of Donald Trump at the White House in 2016, Washington and Beijing have been clashing on almost all global issues, that is, global issues that have domestic implications. In particular, the Trump-administration has been accusing Beijing of practising unfair trade, intellectual property theft, cyber espionage, and more recently for mishandling the origins of the Covid-19 pandemic. While, the contestations between the two powers began long before the rise of Donald Trump, the Trumpian policies such as economic nationalism, narrow patriotism, and protectionism have furthered the clashes. Against this background, the Trump-administration views Beijing as its major competitor in technology development, trade, investment, and finance among others.

On the other side of the ledger, Beijing has equally been accusing Washington for bullying and interfering in the internal affairs of other countries. As such, China is unapologetic about its global geopolitical ambitions. Instead, as the Chinese strategists and publicists have argued, Beijing stands prepared to face up the United States in every respect, be it economical, political, diplomatic, and military (Cordesman 2019). Beijing's newfound confidence is captured in its 2019 Defense White Paper which is a direct response to the United States 2017 National Security Strategy. In this document, Beijing portrays Washington as an aggressor and a no respecter of other nations' sovereignties.

Beijing also points to Trump's intransient attitude to multilateral institutions and agreements including the rhetoric around the building of walls, withdrawal from the Trans-Pacific Trade Partnership Agreement, renegotiation of North Atlantic Tripartite Partnership Treaty, threat of withdrawing from the North Atlantic Treaty Organisation, reduction of development assistance budget to the poor and economically vulnerable countries, and his renunciation of the Paris Climate Change Accord as well as his withdrawal from the World Health Organisation (WHO) at a time when this institution is fighting the deadly coronavirus.

Evidently, the Covid-19 crisis has further deepened the deterioration of US-Sino relations. The Economist Intelligence Unit (2020) was right when it posited that the coronavirus crisis presents an era-defining challenge to global economy and far reaching geopolitical contestations with the United States blaming China for the disease to the extent of designating it as the "Wuhan virus" or "Chinese virus". This is in reference to Wuhan, the city in Hubei province in China where the disease was first identified. As a geopolitical and geoeconomic counter strategic, Beijing has been doling out financial resources and medical supplies as well as dispatching medical experts to support the fight against Covid-19 across the globe and Africa in particular (United States Institute of Peace, 2020; Moyo, 2020a). In this way, Beijing has positioned itself not only as leading the international response to widespread outbreak of the coronavirus on the African continent but also to raise its global profile and demonstrate its importance as a key global player (Cabestan, 2020; International Crisis Group, 2020; The Economist Intelligence Unit, 2020; Moyo, 2020a; Zhou, 2020). 
Tellingly, the leadership deficit exhibited by the United States in the current fight against the coronavirus has allowed Beijing to practice what has been variously dubbed as "mask diplomacy", "coronavirus diplomacy" or "Covid-19 diplomacy" as it tries to repair its reputation on being known as the initial source of the coronavirus global pandemic (Wen \& Hinshaw, 2020). However, even long before the arrival of the Covid-19 on the shores of Africa, the American influence was already diminishing globally, while China under President Xi Jinping has been expanding its global influence especially through its Belt and Road Initiative programme (for a more nuanced analysis of Belt and Road Initiative see Hurley, Morris, \& Portelance, 2018; Breuer, 2017).

\section{Africa in the Midst of Global Geoeconomic Rivalries}

Africa once again finds itself entangled in the middle of the global geoeconomic and geopolitical competition as was the case during the Cold War era. Today, major countries across the globe including the excolonisers such as Germany, France, the UK, Belgium, Canada, and Australia have heightened their business and commercial interests on the African continent. More recently, Brazil, Russia, India, and China have also scaled up their presence in Africa under the rubric of the BRICS club which includes South Africa. It is in this context that Beijing and Washington as the global powers are jockeying for Africa's resources, markets, and diplomatic influence (Desai, 2016).

It must be said at the outset however, that there is a difference in how China and the United States engage with Africa today compared to the previous geopolitical contestations. Apart from trade, investment and finance, the United States policies in Africa are primarily focused on the continent's internal reforms and prospects for democracy and improved human rights and rule of law, in contrast, Beijing espouses the 1955 Bandung principles of mutual respect for sovereignty and territorial integrity; mutual non-non-aggression; non-interference in each other's internal affairs; equality and mutual benefit; and peaceful coexistence (see also Uchehara, 2009: p. 97). As the President of China, Xi Jinping put it in his speech at the opening ceremony of the 2018 Forum on China Africa Cooperation (FOCAC) Summit in Beijing:

“We respect Africa, love Africa, and support Africa. We follow a 'five-no' approach to our relations with Africa: no interference in African Countries' pursuit of development paths that fit their national conditions, no interference in African countries' internal affairs, no imposition of our will on African countries, no attachment of political strings to assistance to Africa; and no seeking of selfish political gains in investment and financing cooperation with Africa. We hope this 'five-no' approach could apply to other countries as they deal with matters regarding Africa. For China, we are always Africa's good friend, good partner and good brother" (cited in United States Institute of Peace, 2020, p. 15).

That aside, it would be noted that the Horn of Africa has become the major theatre of geopolitical and geoeconomic contestations on the African continent. 
Countries such as Djibouti, Ethiopia, Eritrea, Kenya, Somalia, Sudan, and South Sudan have experienced huge doses of geoeconomic and geopolitical instruments including military forays and bases of both China and the United States. As previously mentioned, the geostrategic interests of the two superpowers in Africa include markets, natural resources, energy, security, and the fight against international terrorism as well as containment of each other's expansion on the continent. Thus, beyond the geoeconomic interests, the two powers have been increasingly pursuing diplomatic support of African countries in the United Nations General Assembly (UNGA) and the World Trade Organisation (WTO) multilateral trade negotiation.

Traditionally, the United States together with its Atlantic allies namely the EU, the UK, and Japan have dominated the economic and political spheres in Africa. Yet, as noted above, their influence on the African continent is relatively waning consistent with the erosion of their powers globally. In this vein, China has overtaken the United States as Africa's largest trading partner and as the largest consumer of the African oil. Moreover, China has become a major international player promoting multilateralism in contrast to the United States hegemonism. In this context, China has been generous with financial aid to African countries in the form of grants, debt relief, zero-interest loans, concessional loans, export credits, tariff exemptions, and investment flows especially to the petro-states of the Gulf of Guinea, Chad, and Sudan among others (Moyo, 2020b). Through these geoeconomic instruments, Beijing has been gaining, deepening, and sustaining its geopolitical and geostrategic interests on the African continent.

Apparently, the Forum on China-Africa Cooperation (FOCAC) which was inaugurated in 2000 is the main policy instrument for Beijing's geoeconomic and geopolitical operations in Africa. The dollop of financial flows from China to Africa has been doubled at each FOCAC summit. For example, in 2006 China pledged USD $\$ 5$ billion; in 2009, USD $\$ 10$ billion; in 2012, USD $\$ 20$ billion; in 2015 the pledge tripled to USD $\$ 60$ billion; and also US\$60 billion in Beijing in 2018 (Moyo, 2020b). In addition, FOCAC has expanded China's economic, military and political relations with Africa and informs how Beijing relates with African states including Zimbabwe in matters of peace and security.

No doubt the Chinese military expansion, investments, and rapid growth in Africa have made the Americans uncomfortable, worried, and uneasy. For instance, Beijing has strategically helped build the African Union Head Quarters to the tune of US\$200 million in Addis Ababa; it has appointed a permanent representative to the African Union (AU) as well as to the African Continental Free Trade Area (AfCFTA) in Accra Ghana there by giving China a diplomatic advantage over its erstwhile geopolitical and geoeconomic competitors (Moyo, 2020b). In a Joint statement of the Extraordinary China-Africa Summit against COVID-19 issued on 17 June 2020, African leaders and China stated that:

"In accordance with the FOCAC spirit and long term-values cherished by 
both [Africa and China] sides, we remain committed to extending mutual support on issues regarding each other's core interests and major concerns. China supports African countries in exploring development paths suited to their national conditions and oppose interference in Africa's internal affairs by external forces"

Nonetheless, in 2000 the United States launched its African Opportunity and Growth Act (AGOA) as a geopolitical and geoeconomic instrument. This Act seeks to expand the United States' influence and foster economic and political development in Africa by expanding access to United States trade and investment markets (Ndimande \& Moyo, 2018). However, AGOA has not lived up to its expectations because of some of the resented conditions attached to it. For instance, because of its conditions some African countries including Zimbabwe were excluded from benefiting from AGOA.

To be sure, African leaders prefer political independence and policy space, and yet the objectives of AGOA are challenging the sovereignty of African states. This pushes African leaders towards the Chinese aid as it purportedly comes with no strings attached. Moreover, as noted earlier, the United States' geopolitical position in Africa has been further worsened by Donald Trump who sees African countries as shitholes and has cut aid budgets in pursuit of his "Making America Great Again" vision (see Moyo, 2020b). At the same time, Trump's indifference on racism and police brutality following the murder of an African-American George Perry Floyd in Minneapolis on May 25, 2020 is likely to compound the already battered US image in some African countries.

In short, while the Trump-administration has all too often ignored Africa in its policies, Beijing has quietly established its relations with the continent's political and business elites. Thus, even though the United States still constitutes the strongest global military and geopolitical power, its hegemonic interlude of the post Cold War era is fading as Beijing increasingly challenges its global leadership. Hence, some observers argue that the world has now entered a post-Pax Americana era where the US-China geopolitical and geoeconomic rivalries are reshaping the world order.

\section{Entrapment of Zimbabwe in US-China Rivalries}

Zimbabwe is not immune to the current global geoeconomic and geopolitical rivalries. Many of the key trends affecting global geoeconomics and geopolitics are visible in Zimbabwe. It is argued here that Zimbabwe has been a theatre where the United States and China have been engaging in a marginally acknowledged and latent geoeconomic and geopolitical turfing since the dawn of the $21^{\text {st }}$ century. In this contest, Harare has had closer foreign policy relations with Beijing than with Washington. It will be noted, however that, at present, the calibration of Zimbabwe's ties with these two major powers is under renewed scrutiny, owing to the Second Republic's wish to normalise its relation with the United States and the rest of the international community. 


\subsection{Zimbabwe's Relations with U.S.}

The US-Zimbabwe relations have been tenuous, waxing and waning over the past two decades. The tensions between the two countries emerged in the 1990s when increasing indications of human rights violations, undemocratic governance, and economic decline, accompanied by radical government economic policies and land seizures in Zimbabwe spurred concern in Washington and the rest of the Western capitals (also see Ndimande \& Moyo, 2018; Cook, 2016). In this context, the United States was swift and consistent in condemning human rights violations in Zimbabwe calling for the respect of the rule of law and fundamental human and people's rights.

More importantly, the United States enacted into law the Zimbabwe Democracy and Economic Recovery Act (ZIDERA) in 2001. This move against Zimbabwe signalled the final rupture between Harare and Washington as well as the rest of the Western capitals. To be clear, ZIDERA prohibits the United States support for international financial institutions (IFIs) loans or grants to Zimbabwe's central government, unless and until the Zimbabwean government undertakes economic, political, and electoral reforms (ZIDERA, 2001). In particular, the sanctions included arms embargoes, travel bans, asset freezes and selective banking sanctions for some Zimbabwe African National Union-Patriotic Front (ZANU PF) officials, Military officials, business leaders, and some state-owned enterprises deemed to be key interlocutors of human rights violations. Table 1 below provides an indicative list of some Euro-American multinational companies that left Zimbabwe following the imposition of the restrictive measures over the past two decades.

Table 1. US companies that disinvested from Zimbabwe.

\begin{tabular}{|c|c|c|}
\hline Year & Company & Description \\
\hline 2000 & Lufthansa Swiss Air & Discontinued services in Zimbabwe \\
\hline 2002 & Lonmin plc & Sold Independence Gold Mine to Metallon \\
\hline & & 53 percent stake in the large Bindura Nickel to Mwana \\
\hline 2003 & Anglo-American & $\begin{array}{l}\text { Africa in the wake of simmering conflict among local } \\
\text { business factions for control of the nickel }\end{array}$ \\
\hline 2005 & Anglo American plc & $\begin{array}{l}\text { plc announces that it has sold its } 100 \% \text { shareholding in } \\
\text { Zimbabwe }\end{array}$ \\
\hline 2007 & U.S. company HJ Heinz & $\begin{array}{l}\text { Zimbabwe government bought out its interest stake in } \\
\text { Olivine Industries }\end{array}$ \\
\hline 2008 & Shell & pulled out of Zimbabwe \\
\hline 2008 & Tesco British Airways & $\begin{array}{l}\text { stopped trading with Zimbabwe } \\
\text { stopped services in Zimbabwe }\end{array}$ \\
\hline 2012 & Harven Manufacturing & closed shop \\
\hline 2015 & Rio Tinto & Pulled out \\
\hline
\end{tabular}

Compiled by Authors. 
Apparently, the imposition of targeted sanctions in Zimbabwe brought with it bad publicity, a record low credit rating, and a pariah state tag. As Masaka (2012: p. 51) noted, as a result of sanctions, "investors willingly pulled out of the country, avoided making new investments or were commandeered by their countries not to make new or further investments in Zimbabwe". Not surprisingly, the ruling party-ZANU PF was believed that ZIDERA was mooted as an economic weapon designed to replace its government by economically and financially weakening it, at the same time empowering the political opposition in the country. Faced with sanctions, the then President of Zimbabwe, Robert Mugabe accelerated his rapprochement with Beijing as well as Kremlin (Ndimande \& Moyo, 2018). This marked the beginning of Beijing and Washington low intensity competition in Zimbabwe.

Beijing's support of the rogue regime in Zimbabwe exposed it to tremendous international criticism. For example, Beijing together with the Kremlin used their veto powers as permanent members of the United Nations Security Council (UNSC) to thwart draft resolutions sponsored by the UK and the United States to the United Nations Security Council that condemned Harare's human rights situation. This generated bitter censure from the West for Beijing's shielding of the then Mugabe's government. Concomitantly, Mugabe used the international forums such as United Nations General Assembly (UNGA) and national events as avenues to attack the United States, the UK and the rest of the Western countries for imposing the restrictive measures and targeted sanctions on Zimbabwe. As such, Zimbabwe has been a contentious geopolitical issue in the United Nations Security Council since the early 2000s.

As noted above, the United States in concert with the UK, the EU, Canada, and Australia effectively deployed its geoeconomic instruments in the form of targeted sanctions and financial controls as punitive measures against Harare. Today Zimbabwe is in debt distress largely as a result of these measures. The country's total debt as a percentage of GDP stands at 75 percent and its total debt stock stands at US\$13.13 billion as at 2019 figures (Zimcodd, 2020). The country owes the World Bank US $\$ 1.5$ billion, African Development Bank US $\$ 700$ million, and the European Investment Bank US\$322 million among the other creditors (Moyo, 2020a). Accordingly, it has been rather difficult for Zimbabwe to gain traction in accelerating debt relief due to its tenuous relationship with the United States which has huge influence in some of these international financial institutions and multilateral development banks.

However, while maintaining ZIDERA, the United States government has kept its presence in Zimbabwe visible by providing humanitarian assistance to the needy communities including the victims of Cyclone Idai which left over 270,000 people homeless in the Manicaland Province (Moyo, 2020a). More recently, the United States embassy in Harare has committed over US\$6 million to the fight against Covid-19 in Zimbabwe (United States Embassy in Zimbabwe, 2020). It is also interesting to note that recently, the United States Senate Com- 
mittee Chairman James Risch wrote a letter to the President of the World Bank Group David Malpass to urge the World Bank to put strict accountability and transparency measures to the US\$7 million support to the Covid-19 in Zimbabwe (Moyo, 2020a). The tone of the letter is indicative of the suspicions that continue to exist between Washington and Harare.

In this regard, it will be noted that the United States uses a carrot (humanitarian aid) and a stick (ZIDERA) as its preferred foreign policy approach in Zimbabwe. Some respondents interviewed for this paper noted that the United States uses its values of democracy, respect for human rights and good governance, as a subtle way of encouraging Zimbabwe to move away from China. Ostensibly, the United States policy in Zimbabwe remains geared towards the promotion of democratic governance, entrenchment of a culture of constitutionalism, accountability, rule of law, and civil and political freedoms all of which are antithetical to the Chinese foreign policy.

When Mugabe was ousted by the military in November 2017, there was hope across the globe that Zimbabwe would open another chapter. Some Western countries specifically the UK and the EU countries supported the coup in Zimbabwe simply because they were keen to normalise their relations with Harare. Not surprisingly, the coup beneficiary, President Mnangagwa was invited to attend the World Economic Forum in January 2018 as a sign of his acceptance in the global economic governance stage. Seeing Beijing's monopoly of influence in Zimbabwe as detrimental to their geostrategic interest in Southern Africa, the argument from some observers was that the United States and its Western allies needed to reconsider their isolation and sanctions policy on Harare.

As such, the post-Mugabe administration has been more conciliatory in its approach to the international community. In fact, since his inauguration in November 2017, Mnangagwa has been working on rebuilding his relations with a wider array of countries including the EU, the UK, and the United States. For example, the new government has revised its Indigenisation and Empowerment Act which demanded that all foreign companies should cede 51 percent of their shareholding to the locals (Ndimande \& Moyo, 2018). At the same time, upon his inauguration President Mnangagwa also appointed a pro-Western professor as his Finance Minister in the hope of increasing the chances of the normalisation of relations between his country and the rest of the international community. Moreover, there are claims that the Mnangagwa government has hired a New York-based Mercury Public Affairs LLC as subcontractor to Mercury Internal UK to do some diplomatic lobby and influence the United States Congress, White House, Business, press, and public opinion on behalf of Zimbabwe (Mathuthu, 2020). Indeed, there is a wide belief in Zimbabwe that warmer ties with the Euro-American powers and their juridical economic institutions such as the International Monetary Fund (IMF) and the World Bank may yield many positives for the country. In particular, there is hope that the Euro-American investments in Zimbabwe would contribute to the stabilisation of the economy, 
re-industrialisation, and creation of some new jobs.

Above all, it is important to reiterate that despite all the reported animosity between Harare and Washington, the United States has kept its embassy in Zimbabwe intact. In fact, it has recently constructed one of the most spacious Embassy Buildings in Southern Africa in Harare. This demonstrates that the United States is in Zimbabwe to stay. It will be further noted that since the departure of Ambassador Christopher Dell, in July 2007, who had a particularly acerbic relations with Harare, the United States has been deploying African Americans as ambassadors to Zimbabwe-notably, James D. McGee (2007-2009), Charles A. Ray (2009-2012), David B. Wharton (2012-2015), Harry K. Thomas, $\operatorname{Jr}$ (2015-2018) and Brian A. Nichols (2018-present).

This reflects Washington's sensitivity to Harare's use of racism and neo-colonialism in its engagement with the Western countries. More importantly, it reflects Washington's interest in reducing animosity between the two countries which Zimbabwe should take advantage in going forward. However, some key informants interviewed for this paper observed that in the event of improved ties between Harare and Washington, Zimbabwe will become less dependent on Beijing which makes China unease with any possibility of thawing of relations between Harare and the rest of the international community.

\subsection{Zimbabwe's Relations with China}

Zimbabwe and China have a historical friendship dating back to the time of the liberation struggle in the 1960s and 1970s. The flame of this friendship was rekindled in the early 2000s when the then President Mugabe was shunned by the Euro-American countries over the political and economic crises explained above. In the ensuing period, the United States and the other Western powers isolated Mugabe and sort to break the backbone of his regime through ZIDERA. In response, Mugabe declared his Look East Policy and took substantial efforts to curry Beijing's favours through a wide range of investment incentives (Moyo, 2019). It was at this juncture that China emerged as Zimbabwe's largest foreign investor, a key trading partner, and a very significant source of finance and expertise thereby replacing the key Euro-American actors from Zimbabwe's economic and commercial spheres.

As noted earlier, during this same period, the Euro-American companies, financiers, businesses and farmers left the country for reasons ranging from the land reform programme, racial and xenophobic attacks, and human rights abuses. As a consequent, Chinese state-owned enterprises and Chinese private corporations and individual Chinese entrepreneurs emerged as winners as many large-scale infrastructure projects were granted exclusively to them. Additionally, some of the farms that were previously owned by white commercial farmers were leased to the Chinese.

At the same time, Harare used economic and financial instruments to support the Chinese companies and businesses. Specifically, Chinese were exempted 
from complying with the Indigenisation and Empowerment Regulations and they were allowed to retain 100 percent ownership when all other foreign companies were required to comply with the 51 - 49 percent policy (Government of Zimbabwe, 2020; Ndimande \& Moyo, 2018). Other incentives to the Chinese businesses were in the form of tax exemptions and other related incentives such as tax holidays, tax credits, reduced income tax rates, accelerated depreciation allowances, concessions in export processing zones (EPZ), and import duty waivers. All this was part of Zimbabwe's geo-strategy to reify Beijing while retaliating on the United States and the other Western powers that had imposed sanctions on the country.

Broadly observed, Chinese were awarded with lucrative contracts in the sectors that were historically dominated by the British and the American investors and companies in Zimbabwe. These include among others manufacturing, agriculture, infrastructure, mining, steel and hospitality sectors. In fact, the Chinese investors now top the list of overall investors in Zimbabwe and the mining sector records the highest figures of these investors. Today, examples of China's investment in Zimbabwe include a multimillion dollar deal with China's Tsingshan for chrome, iron ore, nickel and coal mining. The deal initial cost $\$ 2$ billion before rising to between $\$ 5$ billion to US\$10 billion (China Daily, 2019, Newsday, 2019). There are also claims that the new Mnangagwa regime has signed US $\$ 16$ billion worth of investment deals since coming to power in November 2017 (Dore, 2018).

It is also instructive to note that the Chinese built a house for the former President Mugabe, a defense college, and a conference facility for the ruling party ZANU PF, and is currently renovating the Robert Mugabe International Airport and also building a new Parliament in Harare (Moyo, 2020a). This is in addition to a number of other strategic infrastructures such as the power generation, road construction and dam construction. This has evidently increased Beijing's footprint in the country against the United States which is insisting on economic, political, and electoral reforms before it could re-engage Zimbabwe in terms of investment, trade and finance. Beijing's generosity politics has not been an innocent gesture of friendship for the broader population of Zimbabwe but a geoeconomic strategy to keep ZANU PF in power so as to protect its interests in the country.

It is therefore not entirely surprising that Beijing is the most active Zimbabwe's partner in the fight against Covid-19. For example, on 11 May 2020 China sent a team of 12 medical experts along with medical supplies, which included ventilators, nucleic acid testing kits, face masks and medical protective suits inside boxes branded "Good brothers battle together" a message of solidarity to help Zimbabwe fight Covid pandemic (CGTN, 2020; Xinhua, 2020). At the same time, two Chinese companies Huawei and Sichuan PD Times handed 50,000 medical surgical masks, 510 protective suits and 1000 pairs of medical goggles to enable the country to fight the coronavirus (Xinhua, 2020). It is on 
this basis that Harare continues to view Beijing as its all-weather friend, an economic messiah, and a dependable development partner.

Ironically, despite the much celebrated thesis of an all-weather friend, Zimbabwe's relationship with China has been characterised by capital flight, tax evasions, externalization of foreign currency, corruption, high unemployment and continued effects of international isolation. Tax evasions have particularly benefitted Chinese companies like the technology giant Huawei depriving the country of the much needed foreign currency. In this context, Zimbabwe has been accumulating debt from China which has actually became a burden to the fiscus, of course some of these loans were secured through resources such as diamonds and platinum. Table 2 below provides an indicative list of some of the Chinese loans to Zimbabwe between 2000 and 2019.

These loans add to all the other debts that were contracted by Harare since independence and the country is now in debt distress. Furthermore, there is fear that with Zimbabwe unable to realistically pay back any loans that have been offered, Beijing would take full ownership of some of these projects like it did with the Hambantota port in Sri Lanka (Moyo, 2020a). Hence some American scholars and policy makers have been cautioning African countries about Beijing describing it as an economic hawk, a resource colonialist, a mad dash, a resource grabber, a land grabber, a new scrambler, a new-imperialist, a sub-imperialist, a rogue donor, a rogue creditor, a predatory lender, an anti-democracy, and an anti-liberal country. Moreover, to the generality of Zimbabweans, Chinese cheap imports, lack of respect for human and labour rights as well as environmental degradation are cause for concern.

Overall, it would be noted that the United States' policy on Zimbabwe has been focused on Harare itself and the success of its transition to democratic governance and development. From long opposing human rights abuses, rule of law, corruption, and abuse of power, most of the United States policy initiatives, if not all, have been focused on Zimbabwe's domestic political and economic and social development with little direct relevance to Beijing. However, because Beijing has had such extensive political, economic, and military footprint in Zimbabwe, mostly associated with ruling Military-Executive alliance, it is inevitable for observers to view the US-Sino ties in Zimbabwe as exhibiting low intensity geoeconomic competition. More crucially, it is worth noting that the two global powers have intentionally avoided framing Zimbabwe in the context of broader US-Sino relations.

\section{Defining Winners and Losers}

Given the foregoing discussion on Zimbabwe's entanglement in the US-China geoeconomics, the quintessential questions are: Who are the winners? Who are the losers? And are there any opportunities for the troubled country? This section points to some preliminary hypotheses about the implications of the US-Sino contestation in Zimbabwe. 
Table 2. Chinese financial support to zimbabwe.

\begin{tabular}{|c|c|c|c|}
\hline Year & Amount US\$ & Loan & Purpose \\
\hline 2000 & $\$ 2,400,000.00$ & Concessional loan & Not Specified \\
\hline 2001 & $\$ 3,600,000.00$ & Concessional loan & Not Specified \\
\hline 2002 & $\$ 8,300,000.00$ & Concessional loan & Agriculture Equipment \& Inputs \\
\hline 2003 & $\$ 70,000,000.00$ & Concessional loan & Power Generation \\
\hline 2004 & $\$ 1,000,000,000.00$ & Concessional loan & Kariba Hydro Power Station \\
\hline 2006 & $\$ 200,000,000.00$ & Concessional loan & Agricultural Inputs \\
\hline 2007 & $\$ 58,000,000.00$ & Concessional loan & Tobacco Farming \\
\hline 2008 & $\$ 200,000,000.00$ & Concessional loan & Internal-Security \\
\hline 2009 & $\$ 200,000,000.00$ & Export Buyers' Credit & Not Specified \\
\hline \multirow{2}{*}{2010} & $\$ 46,000,000.00$ & Concessional loan & Agricultural Inputs \\
\hline & $\$ 30,000,000.00$ & Concessional loan & Agriculture Machinery \\
\hline \multirow[t]{2}{*}{2011} & $\$ 342,000,000.00$ & Concessional loan & Medicine \\
\hline & $\$ 162,000,000.00$ & Concessional loan & Victoria Fall Airport \\
\hline \multirow[t]{2}{*}{2012} & $\$ 45,000,000.00$ & Concessional loan & Telecommunication \\
\hline & $\$ 51,000,000.00$ & Concessional loan & infrastructure \\
\hline 2013 & $\$ 319,000,000.00$ & Concessional loan & Power Generation \\
\hline \multirow{2}{*}{2018} & \multirow{2}{*}{$\begin{array}{l}\$ 1,000,000,000.00 \\
\$ 77,000,000.00\end{array}$} & \multirow{2}{*}{$\begin{array}{l}\text { Concessional loan } \\
\text { Concessional loan }\end{array}$} & Hwange Power Station \\
\hline & & & $\begin{array}{l}\text { Construction of a New } \\
\text { Parliamentary Building }\end{array}$ \\
\hline 2019 & $\$ 153,000,000.00$ & Concessional loan & $\begin{array}{l}\text { Refurbishment of Robert Mugabe } \\
\text { Airport }\end{array}$ \\
\hline
\end{tabular}

Compiled by Authors

Arguably, Beijing tops the list of the winners in the US-China geoeconomic competition in Zimbabwe. When the Anglo-American corporations disinvested from Zimbabwe due to risks caused by sanctions, Chinese investors acted opportunistically and replaced them. As previously mentioned, since then China has deployed its massive geoeconomic instruments including investments, trade, finance, loans, technical and cultural as well as diplomatic resources to expand its footprint in Zimbabwe. Consequently, Beijing has massively increased its foreign direct investment and loans in Zimbabwe where it continues to expand its access to commodities, particularly by investing in mining, telecommunications, construction, agriculture, infrastructure, roads, and airports as well as power generation. It is now the second largest trading partner of Zimbabwe after South Africa. China has its footprint firmly fixed on the key levers of the economy in Zimbabwe where in the past the Euro-American companies such as Anglo-American Corporation, De Beers, Lonrho, Rio Tinto, and others claimed decisive influence. Of course, others such as the Standard Chartered Bank, Old Mutual Unilever East and Central Africa, and British American Tobacco among others remained operating in the country signifying the importance of Zimbabwe to their business strategies. 
Controversially, ZANU PF as an institution also features as a relative winner in the US-China geoeconomic contestations. The geoeconomic instruments including sanctions, financial controls, and arms embargo marshalled by the United States and its allies in particular, the UK, the EU, Canada and Australia were meant to either induce good behaviour on the part of ZANU PF leadership or create conditions for the change of government. However, these two objectives have not been realised, instead, the geoeconomic instruments have enabled ZANU PF to forge even stronger alliances with the anti-Western sentiments and countries which bolstered it to resist any change of behaviour and government. Evidently, the sanctions targeted narrowly against the rogue ZANU PF government have not been adequate to achieve coercive goals and regime change. Instead, the ZANU PF has reconsolidated its ties with the Chinese Communist Party (CCP) as evidenced by the frequency of visits and the special connection between the two parties (Moyo, 2019). In the process, CCP has been one of the major financiers of ZANU PF's electoral machinery including its paraphernalia and campaign vehicles since early 2000 s.

In contrast, the United States and the other Western countries and their multinational corporations have been hurt in Zimbabwe. They have emerged as loosing/losers as they have lost ground in terms of investment, trade and business opportunities in Zimbabwe. In fact, the Euro-American investors and multinational corporations have been relatively disadvantaged as more of the business and investment opportunities are taken up by the Chinese in Zimbabwe. In fact, it appears that United States sanctions as well as the retreat by the Anglo-American multinational corporations provided a golden opportunity for China and other emerging economies to gain market access, resources, and influence in Zimbabwe.

For example in the agro-business, TianZe Tobacco Company (TZTC) a subsidiary of China National Tobacco Company (CNTC) in Zimbabwe was established in Harare in 2005 (Fang et al., 2020). TZTC has been actively involved in the sector through contract farming and provisioning of free technical services. Today Tobacco exports constitute about 71 percent of all Zimbabwean exports to China. Furthermore, Chinese companies in the cotton sector include Sino Zim Cotton Holdings Pvt Ltd established in 2009; Viridis and Jinmac in 2011; Sinotex in 2012; and in 2013 China-Africa Cotton Development Limited which merged two cotton companies in Zimbabwe and founded China-Africa Cotton Zimbabwe (PVT) Limited, which became the second largest cotton company in Zimbabwe (Chipaike \& Bischoff, 2019; Weng et al., 2018).

The Chinese footprint is ubiquitous in the mining sector. For example, in 2007 Sino Steel Corporation acquired a 50 percent stake in Zimbabwe's largest ferrochrome producer, Zimbabwe Mining and Smelting Company (ZIMASCO) Consolidated Enterprises Ltd which produces 210,000 tonnes of high carbon ferrochrome annually, and in August 2007 China North Industries Corporation (Norinco) made investment in Hwange Colliery Mine (Chipaike \& Bischoff, 
2019). At the same time, the Chinese companies that is, Jinan and Anjin have been in a partnership with the Ministry of Defense since 2009 (Alao, 2014; The Herald, 2019). The foregoing examples only represent a snapshot of the Chinese private corporations, state owned companies and entrepreneurs that now dominate the economic spheres in Zimbabwe.

What cannot be doubted is that Beijing has deepened its geoeconomic footprint in Zimbabwe at a time when the Anglo-American companies have been handicapped by the sanction regimes. Moreover, with more and more industry value chains now passing through the orbit of the Chinese trade system, the United States and other Western companies interested in investing in Zimbabwe will have to adapt to Chinese geoeconomics (Moyo, 2019). In other words, the more the Euro-American powers maintain sanctions in Zimbabwe the more the Chinese entrench themselves thereby wining the geopolitical and geoeconomic competition against their erstwhile global competitors. Thus, given the challenges that the United States faces today competing in the global markets, Lektzian and Biglaiser (2013: p. 76) were right in noting that it is "unwise for United States policy makers to continue implementing policies that are likely to have a chilling effect on its business interests abroad".

However, top of the losers list are the people of Zimbabwe who have become collateral damage in the geoeconomic frictions. There is no doubt that the squabbles between Zimbabwe and the United States, the UK, and the EU among the other key external actors have led to sustained disinvestment and de-industrialisation that have severely weakened the economy with negative consequences for the livelihoods of millions of people. Zimbabwe government claims the country has lost over US $\$ 42$ billion as a result of the Euro-American restrictive measures (AllAfrica, 2019). Today, Zimbabwe faces its worst economic turmoil characterised by cash, water, fuel, and power shortages among the many other social and economic ills. Moreover, since the enactment of ZIDERA in 2001, Zimbabwe has lost on opportunities to get concessional loans and grants from the International Financial Institutions and it has been difficult for country to access funds needed for the prevention and treatment of HIV/Aids from the Global Fund (Chingono, 2010). The same vein, the country has not benefited from African Growth and Opportunity Act (AGOA) while other African countries which have normal bilateral relations with the United States have been able to export their agricultural produce duty free to the United States since 2000 (Ogbona, 2017).

\section{Gesturing into the Future}

It is the argument of this article that being caught between Washington and Beijing geoeconomic contestations could be enviable if Zimbabwe is able to effectively balance between the two superpowers and extract the benefits, but in order to do that, the state itself must be strong enough that it does not get taken advantage of by one or both of them. In this respect, government should continue 
engaging other partners including, India, Russia, Saudi Arabia, Turkey, the EU and the UK among others. This will boost the country's prospects of balancing between the United States and China in this era of geoeconomic frictions.

Given the global geoeconomic frictions, navigating the complicated and sensitive issues of US-China relations is tricky and requires political maturity, diplomatic adeptness, and government capacity that the current Mnangagwa administration does not seem to possess nor prioritises at this moment in time. The challenge is that the Zimbabwe government approaches both countries looking for a saviour. Its initial relationship with the United States seems to have been a product of the Washington Consensus and Zimbabwe was in it for aid and foreign direct investment. In the same vein, its declaration of the Look East Policy was in search for a saviour from the sanction regime. This explains some of the difficulties that Zimbabwe faces amid the US-China geoeconomic competition.

So far the available evidence indicates that the Mnangagwa administration has been struggling to reset and reconfigure Zimbabwe's relations with the rest of the international community let alone the United States. Its rhetoric on political, economic and electoral reforms has fallen far short of addressing the expectations of the United States, the EU, and the UK among the other traditional development partners (Ndimande \& Moyo, 2018). Zimbabwe government must exercise its agency and build a cumulative and positive relation with the United States and the rest of the international community as much as it has done with Beijing. In other words, while accepting the strategic importance of Beijing, Harare should also realise the importance of the United States and the other Western countries' cooperation in its bid to stabilise its ailing economy.

This will mean government earnestly committing to democratic governance including undertaking economic, political, and electoral reforms. Not only to please the Western countries but also because these reforms are demanded by Zimbabweans themselves. With little movement in the areas of corruption, elections, legislation, human rights, and the partisan nature of state institutions, particularly the security sector and the judiciary, there is little chance for re-engagement with the Euro-American countries that have been pushing for a reform agenda in Zimbabwe. Whether Zimbabwe government is capable or willing to take advantage of the US-China geoeconomic rivalries remains unclear.

\section{Conclusion}

The article concludes that while Zimbabwe is entrapped in the U.S-China geoeconomic frictions, government does not have to choose between Beijing and Washington but should maintain good relations with both powers. As indicated, currently ordinary people top the list of losers in the US-China geoeconomic competition. To transform this unhealthy situation, Zimbabwe government needs to commit both to warmer relations with Washington as well as pursuing a comprehensive strategic cooperative partnership with Beijing. As such, gov- 
ernment should take advantage of the growing US-China strategic and economic competition to improve its bargaining power with both and reduce the undesirable effects of a close but also asymmetrical relationship with Beijing. Without this approach, the United States is likely to continue on its trajectory of human rights, rule of law, civil and political freedoms, and democratic governance promotion while China will obviously scale-up its heavy lifting resource extraction, infrastructure investment, trade expansion and arms deal for years to come leaving Zimbabweans poorer in the process. Finally, it would be noted that this study faced three major limitations. First, the researchers did not have the opportunity to interview the Chinese and American diplomats who are accredited to Zimbabwe who could have given their perspective on the issues raised in this article. Second, Zimbabwe is not a key geostrategic country for both Beijing and Washington as South Africa, Kenya, Nigeria, Ethiopia, and Egypt are. For that reason, there is scanty literature on US-China geoeconomic competition in Zimbabwe. Third and final, the study itself did not carry out a comparative analysis of the levels of trade, investment, and finance in quantitative terms. This would have provided a clearer picture about the magnitude of the geoeconomic competition between Beijing and Washington in Zimbabwe. Therefore, future researchers should consider carrying out comparative and quantitative studies on the levels of investment, trade and finance from China and the United States over the last two decades in Zimbabwe.

\section{Conflicts of Interest}

The authors declare no conflicts of interest regarding the publication of this paper.

\section{References}

Alao, C. (2014). China and Zimbabwe: The Context and Contents of a Complex Relationship. SIIA Occasional Paper, 202, Pretoria: Global Powers and Africa Programme. https://media.africaportal.org/documents/saia_sop_202_alao_21041017.pdf

Allafrica (2019). Zimbabwe: Sanctions Have Cost Zimbabwe U.S. \$42 Billion, Government Claims. https://allafrica.com/stories/201909110276.html

Barton, B. (2018). China's Security Footprint in Africa: Towards an Evolution of the Application of Its Non-Interference Principle?

https://theasiadialogue.com/2018/10/04/chinas-security-footprint-in-africa-towards-an -evolution-of-the-application-of-its-non-interference-principle

Breuer, J. (2017). Two Belts, One Road? The Role of Africa in China's Belt and Road Initiative. Köln: Stiftung Asienhaus.

http://crossasia-repository.ub.uni-heidelberg.de/4092/1/Breuer-2017.pdf

Cabestan, P. J. (2020). China's Battle with Coronavirus. Possible Geopolitical Gains and Real Challenges.

https://studies.aljazeera.net/en/reports/china\%E2\%80\%99s-battle-coronavirus-possible -geopolitical-gains-and-real-challenges

CGTN (2020). Chinese Doctors Arrive in Zimbabwe to Aid Fight against COVID-19. https://news.cgtn.com/news/2020-05-12/Chinese-doctors-arrive-in-Zimbabwe-to-aid-f 
ight-against-COVID-19-Qqix1NSSnm/index.html

China Daily (2019). Zimbabwe Signs Multibillion-Dollar Mining Deal with Chinese Company. http://www.chinadaily.com.cn/a/201904/24/WS5cbf4398a3104842260b7df5.html

Chipaike, R., \& Bischoff, P. H. (2019). Chinese Engagement of Zimbabwe and the Limits of Elite Agency. Journal of Asian and African Studies, 54, 947-964. https://doi.org/10.1177/0021909619848783

Chingono, H. (2010). Zimbabwe Look East Policy. China Monitor. Stellenbosch: Centre for Chinese Studies.

Cook, N. (2016). Zimbabwe: Current Issues and U.S. Policy. Washington DC: Congressional Research Service. https://fas.org/sgp/crs/row/R44633.pdf

Cordesman, H. A. (2019). China and the U.S.: Cooperation, Competition and/or Conflict an Experimental Assessment.

https://csis-website-prod.s3.amazonaws.com/s3fs-public/publication/191001_China_G rand_Strategy.pdf

Desai, M. (2016). US Power Dynamics in Africa: A Critical Geopolitical Reading of US Security Policies in Kenya in the Post-9/11 Era. Lund: Lund University.

http://lup.lub.lu.se/luur/download?func=downloadFile\&recordOId=8875097\&fileOId= 8878993

Dore, D. (2018). The Art of Creating Money: An Appraisal of Zimbabwe's Economy. Southern Africa Report 18 (November), ISS: Pretoria.

https://media.africaportal.org/documents/Art_of_creating_money.pdf

Government of Zimbabwe (2020). Statutory Instrument 25 of 2020. Income Tax (Exemption from Income Tax) (Huawei Technologies Co., Ltd.) (Amendment) Notice, 2020 (No. 1). Harare.

http://www.veritaszim.net/sites/veritas_d/files/SI\%202020-025\%20\%20Income\%20Tax \%20\%28Exemption\%20from\%20Income\%20Tax\%29\%20\%28Huawei\%20Technologies \%20Co.\%2C\%20Ltd.\%29\%20\%28Amendment\%29\%20Notice\%2C\%202020\%20\%28No \%201\%29.pdf

Fang, J. et al. (2020). “All Weather Friends": How China Transformed Zimbabwe's Tobacco Sector. International Journal of Environmental Research and Public Health, 17, 723. https://doi.org/10.3390/ijerph17030723

Hurley, J., Morris, S., \& Portelance, G. (2018). Examining the Debt Implications of the Belt and Road Initiative from a Policy Perspective. CGD Policy Paper 121, (March 2018), CDD.

https://www.cgdev.org/sites/default/files/examining-debt-implications-belt-and-road-i nitiative-policy-perspective.pdf

International Crisis Group (2020). COVID-19 and Conflict: Seven Trends to Watch Crisis Group Special Briefing No. 4.

https://www.crisisgroup.org/global/sb4-covid-19-and-conflict-seven-trends-watch

Lektzian, D., \& Biglaiser, G. (2013). Investment, Opportunity, and Risk: Do US Sanctions Deter or Encourage Global Investment? International Studies Quarterly, No. 57, 65-78. https://doi.org/10.1111/j.1468-2478.2012.00761.x

Luttwak, E. (1990). From Geopolitical to Geo-Economic: Logic of Conflict, Grammar of Commerce. The National Interest, 20, 17-25.

Masaka, D. (2012). Paradoxes in the "Sanctions Discourse" in Zimbabwe: A Critical Reflection. African Study Monographs, 33, 49-71.

https://www.researchgate.net/publication/277041234_PARADOXES_IN_THE_'SANC 


\section{TIONS_DISCOURSE'_IN_ZIMBABWE_A_CRITICAL_REFLECTION}

Mathuthu, M. (2020). Lobbying Firm Paid by Zimbabwe Does Khuphe's Bidding in Washington: We Must Not Forget It Is a New Day in Zimbabwe.

Moyo, G. (2020a). Chinese Development Finance to Africa and the Spectre of Debt Distress. In S. Oloruntoba (Ed.), The Palgrave Handbook of African Political Economy. Berlin: Springer International Publishing.

Moyo, G. (2020b). Obstacles and Opportunities for Financing the Fight against Covid-19 Pandemic in a Debt Trapped Zimbabwe. iBusiness, 12, 52-68.

https://www.researchgate.net/publication/342356779_Obstacles_and_Opportunities_fo r_Financing_the_Fight_against_Covid-19_in_the_Debt_Trapped_Zimbabwe https://doi.org/10.4236/ib.2020.122004

Moyo, G. (2019). The Fetishised Role of External Actors in Zimbabwe's 2018 Elections: Implications for the Future, Plebiscites. Africana Studia, 31, 141-157. https://ojs.letras.up.pt/index.php/1_Africana_2/article/viewFile/7019/6449

Nantulya, P. (2019). Chinese Hard Power Supports Its Growing Strategic Interests in Africa.

Ndimande, J., \& Moyo, G. K. (2018). “Zimbabwe Is Open for Business”: Zimbabwe's Foreign Policy Trajectory under Emmerson Mnangagwa. Afro Asian Journal of Social Sciences, 9, 2229-5313.

https://www.researchgate.net/publication/327982537_'ZIMBABWE_IS_OPEN_FOR_B USINESS'_ZIMBABWE'S_FOREIGN_POLICY_TRAJECTORY_UNDER_EMMERSO N_MNANGAGWA

Newsday (2019). GVT Pens $\$ 5$ Billion Mining Deal. https://www.newsday.co.zw/2019/04/govt-pens-5-billion-mining-deal

Ogbona, C. C. (2017). Targeted or Restrictive: Impact of U.S. and EU Sanctions on Education and Healthcare of Zimbabweans. Bahir Dar: Ethiopia. https://doi.org/10.4314/afrrev.v11i3.4

Pacific Tech (2018). Geoeconomics and Strategy. https://www.canon-igs.org/event/report/180529_Goldstein_presentation.pdf

The Herald (2019). Govt Okays Anjin, AlrosaChiadzwa Ops.

The Economist Intelligence Unit (2020). Geopolitics after Covid-19: Is the Pandemic a Turning Point? https://www.demdigest.org/wp-content/uploads/2020/05/geopolitics-after-covid19.pdf

Uchehara, E. K. (2009). China-Africa Relations in the 21st Century: Engagement, Compromise and Controversy. Uluslararasr, Iliskiler, 6, 95-111.

https://www.uidergisi.com.tr/wp-content/uploads/2013/02/China-Africa-Relations.pdf

United States Embassy in Zimbabwe (2020). United States Assistance to Zimbabwe's COVID-19 National Response Now Exceeds US \$6 Million.

https://zw.usembassy.gov/united-states-assistance-to-zimbabwes-covid-19-national-res ponse-now-exceeds-us6-million

United States Institute of Peace (2020). China's Impact on Conflict Dynamics in the Red Sea Arena. Washington DC: United States Institute of Peace. https://www.usip.org/publications/2020/04/chinas-impact-conflict-dynamics-red-sea-a rena

Wen, P., \& Hinshaw, D. (2020). China Assert Claim to Global Leadership, Mask by Mask. Wall Street Journal, April.

https://www.wsj.com/articles/china-asserts-claim-to-global-leadership-mask-by-mask$\underline{11585752077}$ 
Weng, X. et al. (2018). Chinese Investments and Africa's Small-Scale Producers: Disruptions and Opportunities: Empirical Analysis of Primary Sectors in Tanzania, Zambia and Zimbabwe. IIED Research Report, London: IIED.

https://pubs.iied.org/pdfs/13605IIED.pdf

Xinhua (2020). Chinese Companies Donate Medical Supplies to Zimbabwe. http://www.xinhuanet.com/english/2020-04/22/c_138997841.htm

Zhou, L. (2020). Will China's Support for Nations Fighting Covid-19 Improve Its Global Image?

https://amp.scmp.com/news/china/diplomacy/article/3076276/will-chinas-support-nati ons-fighting-covid-19-improve-its

ZIMCODD (2020). Zimbabwe COVID-19 Response Mechanism: The Resource Factor. http://zimcodd.org/wp-content/uploads/2020/04/COVID-19-Response-Mechanism.pd $\underline{\mathrm{f}}$

Zimbabwe Democracy and Economic Recovery Act of 2001, Public Law 107-99-DEC. 21, [S. 494]. https://www.congress.gov/107/plaws/publ99/PLAW-107publ99.pdf 